\title{
Gene Therapy Approaches to Immunodeficiency
}

Sujal Ghosh, MD, ${ }^{1,2}$ H Bobby Gaspar, MBBS, PhD, ${ }^{1}$

${ }^{1}$ Infection, Immunity, Inflammation, Molecular and Cellular Immunology Section, University College London - Great Ormond Street Institute of Child Health, London, United Kingdom

${ }^{2}$ Department of Pediatric Oncology, Hematology and Clinical Immunology, Medical Faculty, Center of Child and Adolescent Health, Heinrich-Heine-University, Düsseldorf, Germany

\section{Corresponding address:}

Professor Bobby Gaspar

GOSHCC Professor of Paediatrics and Immunology

Consultant in Paediatric Immunology

Infection, Immunity, Inflammation, Molecular and Cellular Immunology Section, University

College London - Great Ormond Street Institute of Child Health, London, United Kingdom, 30

Guilford Street, London WC1N 1EH

T: +44 (0)207905 2319/2809 (direct/secretary)

F: +44 (0)207905 2810

E: h.gaspar@ucl.ac.uk

\section{Key Words}

- Gene Therapy

- Primary Immunodeficiency

- Adenosine Deaminase Deficiency

- X-Linked Severe Combined Immunodeficiency 
- Chronic Granulomatous Disease

- Wiskott-Aldrich Syndrome

\section{Abstract}

Transfer of gene-corrected autologous haematopoietic stem cells in patients with primary immunodeficiencies has emerged as a new therapeutic approach in the last three decades. Patients with various conditions lacking a suitable donor for transplant have been treated with retroviral vectors and a gene-addition strategy. Initial promising results were shadowed by the occurrence of malignancies in some of these patients. Current trials, developed in the last decade, employ safer viral vectors to overcome the risk of genotoxicity and have led to improved clinical outcomes. This review reflects the progresses made in specific disorders including adenosine deaminase deficiency, X-linked severe combined immunodeficiency, chronic granulomatous disease and Wiskott-Aldrich syndrome. The success of these studies suggests that gene therapy has the potential to become a standard therapeutic option in the care of patients with these disorders.

\section{Key Points}

- Ex-vivo gene transfer can be employed in different primary immune disorders

- Initial results were tempered by genotoxicity associated with the gammaretroviral design

- New "safer" vector designs combined with non- or fully myeloablative conditioning regimens allow enhanced engraftment and efficient transgene expression, while maintaining a robust safety profile 


\section{Introduction}

More than 300 gene defects have been associated with primary immunodeficiency syndromes (PID). ${ }^{1}$ Treatment strategies encompass anti-infective prophylaxis and immunoglobulin substitution. However, haematopoietic stem cell transplantation has been the only option for definitive correction and functional reconstitution. Transplant-related mortality due to toxicity and infections are major concerns even in a fully matched setting. Despite emerging reduced-intensity conditioning regimens, a mismatched donor may lead to a fatal outcome in some patients. ${ }^{2}$ Ex-vivo gene transfer of autologous haematopoietic stem cells has been progressively developed in the past decades. Initial studies using gammaretroviral vectors showed success but also major safety issues due to insertional mutagenesis, which ultimately led to a range of newly developed safer vectors and promising current phase I / phase II trials. At least in one of the diseases, namely adenosine deaminase deficiency, it seems gene therapy is an equal or even slightly superior treatment to current standards of treatment with fully matched unrelated donors. Besides safety concerns, one major challenge of the future will certainly be the accessibility of gene therapy in other centres than the current few ones in high-resource countries.

\section{Adenosine deaminase (ADA) deficiency}

Adenosine deaminase is essential in the purine salvage pathway and catalyses the deamination of metabolites into deoxyinosine and inosine. As it is ubiquitously expressed, mutations in $A D A$ lead to accumulation of toxic deoxyadenosine triphosphate and adenosine triphosphate and subsequently to immunological, pulmonary, gastrointestinal, skeletal, and neurological abnormalities. ${ }^{3}$ Affected infants present usually with a T-B-NK- SCID phenotype in the first months of life with failure to thrive and severe infections. Weekly enzyme 
replacement therapy with pegylated bovine ADA allows partial numeric and functional T cell reconstitution; however long-term results show limited sustained efficacy. HSCT has been considered as the only curative treatment for a long time and success rates reach $90 \%$ in patients with a matched-sibling or matched-family donor without the need of any conditioning. However, the transplantation of MUD or haploidentical grafts is associated with inferior results (1-year survival: MFD 90\%, MUD 67\%, haplo 43\%)

Gene correction of peripheral blood lymphocytes and later of haematopoietic progenitor cells has been attempted from the early 1990s. Initial studies at NIH Bethesda and San Raffaele in Milan with gammaretroviral vectors and concomitant ERT showed low toxicity, but lack of substantial immunological and clinical benefit due to low levels of marked cells in the peripheral circulation. ${ }^{5-8}$ The next generation of trials in Milan and London incorporated the idea of conferring a greater competitive advantage to transduced cells and so PEG-ADA was stopped prior to gene therapy and furthermore a non-myeloablative reduced intensity conditioning (RIC) regimen with Busulfan or Melphalan was given to enhance engraftment. The trial at Children's Hospital Los Angeles and NIH amended its protocol after treating the first patients without conditioning. ${ }^{4,9,10}$ Implementation of conditioning led to a more favourable outcome in all patients compared to the initial studies. Murine studies confirmed the findings of the positive effect of prior cytoreduction but it seems that cessation of ERT is of less importance, and ERT continuation showed significantly increased levels of genemodified cells in the thymus in mice. ${ }^{11}$ Based on that, current trials allow the continuation of ERT until day 30. Together the three gammaretroviral studies treated over 40 patients with gammaretroviral vectors and all patients are alive. Approximately $75 \%$ of patients are off ERT and transduced cells engrafted permanently with partial reconstitution in all lineages (unpublished). Notably, none of the patients have developed insertional mutagenesis, 
although in all studies, patients harbour integration events near proto-oncogenes, including LMO2 as a consequence of being treated with a gammaretroviral vector. The positive outcome and the excellent survival in ADA deficiency led to the market authorisation of the Milan gammaretroviral vector by the European Medicines Agency (Strimvelis ${ }^{\mathrm{TM}}{ }^{\text {). }}{ }^{12}$

Given the adverse events using gammaretroviral vectors in other gene therapy studies, our group in London and the group at UCLA decided to proceed to further trials using a lentiviral vector. A codon-optimized human cDNA ADA gene under the control of the short form elongation factor-1 alpha promoter (EF1 $\alpha)$ was shown to have efficacy in the murine model ${ }^{13}$. Furthermore safety issues assessed through in vitro immortalization indicated a reduced transformation potential compared to gammaretroviral vectors. Interim data from these 2 studies using the lentiviral vector again show $100 \%$ survival and impressive immune and metabolic correction. ${ }^{14}$

\section{X-linked severe combined immunodeficiency (SCID-X1)}

Mutations in the IL2RG gene encoding the common gamma chain on the X-chromosome lead to one of the most common form for SCID. The gamma chain is a key subunit shared by different cytokine receptor complexes for IL-2, IL-4, II-7, II-9, II-15 and IL-21. Hence, SCID-X1 patients with defective gamma chain function have profound cellular (due to decreased T cell number and function) and humoral (due to decreased B cell function) defects with typically a T-B+NK- phenotype. ${ }^{15}$

There are rare cases of patients with spontaneous reversion of the mutation in a fraction of cells leading to the correction of immunodeficiency in these individuals. ${ }^{16}$ This phenomenon supported the concept of selective advantage of "gene-corrected" cells over mutated lymphocytes and thus the principle of gene therapy. The first generation of gammaretroviral 
vectors were applied to haematopoietic stem cells in a total of 20 patients, lacking an HLAidentical donor, in studies in Hôpital Necker, Paris and Great Ormond Street Hospital, London. ${ }^{17-19}$ In both studies a gammaretroviral vector derived from a defective Moloney murine leukemia virus (Mo-MLV) was used, in which IL2RG expression was driven by the viral LTR. Ex-vivo transduced autologous CD34+ cells were given to patients without any conditioning, and in most patients a rapid and sustained functional and numeric reconstitution of T cells (with high levels of gene marking) was seen. NK cells engrafted transiently to a lesser extent, and humoral reconstitution allowed the discontinuation of immunoglobulin replacement therapy in less than $50 \%$ of treated patients. It is likely that this level of reconstitution results from the engraftment of more committed progenitor cells rather than true hematopoietic stem cells as has been observed in other unconditioned allogeneic HSCT procedures. A similar approach was initiated in five older patients with hypomorphic IL2RG mutations (including 3 treated at the NIH), but despite good marking in all lineages, functional reconstitution was not achieved. A lack of thymopoietic capacity due to age-related decreased function may be related to the insufficient outcome. ${ }^{20}$

The promising outcome in XSCID patients was shadowed by the occurrence of genotoxicity from approximately two years after treatment. ${ }^{18,21,22} \mathrm{~A}$ total of five clinically well patients in both centres developed acute lymphoblastic T cell leukaemia, four of whom entered remission with standard chemotherapy and then showed recovery of gene corrected cells and restored immunity. One patient died due to incurable refractory leukaemia despite allogeneic HSCT. Extensive investigations performed at this time revealed the pathophysiology of insertional mutagenesis in all cases of malignancies, which could be linked to features of the gammaretroviral vector used. The tendency for preferential gammaretroviral integration near transcription start sites together with enhancing activity of the viral LTR most likely led to 
aberrant transcription and expression of neighbouring oncogenes (LMO2) or cell cycle regulators (BMI1 and CCND2). Furthermore accumulation of other abnormalities in genes such NOTCH1 and CDKN2A were detected in the blast population and most likely led finally to leukaemic transformation. The severe outcome seen in these and other PID trials (see below) led to a global re-design of most on-going clinical gene therapy trials, notably in the configuration of the vectors. Self-inactivating (SIN) gammaretro- and lentiviral vectors incorporate safety features such as the deletion of the viral LTR with transcription of the transgene under the control of an internal mammalian promoter. Various in-vivo and in-vitro models showed that the risk of insertional mutagenesis was significantly reduced with the use of SIN vector designs. Based on these concerns, two SIN vectors have been developed. One SIN gammaretroviral vector under the control of an internal EF1alpha promoter and deletion of the original Mo-MLV U3 LTR enhancer ${ }^{23}$ has been employed in a multi-centre approach to XSCID in Boston, Cincinnati, London, Los Angeles and Paris and 10 patients have been treated so far. ${ }^{24}$ Conditioning was initially not given to most patients (only in those with maternal engraftment or maternal GvHD) and 9/10 boys survived. One patient died due to pre-existing adenoviremia, and one patient had to undergo another stem cell procedure with a mismatched cord blood graft due to absent gene marking. All other patients show a similar T cell reconstitution to that seen in the previous gammaretroviral studies, with significant reduction of infections, but with the majority still retaining dependence on immunoglobulin replacement. With regards to genotoxicity, clustering of viral integrations around oncogenes was significantly decreased in comparison to gammaretroviral studies. Moreover clonal expansion, persistence or dominance was not seen in any if the patients treated with the longest follow up $>5 y$ rs in the first patient treated . Another trial in older patients (7-23 years old) conducted at $\mathrm{NIH}$, included the application of a SIN lentivirus using an EF1alpha promoter 
to drive a codon-optimized gc cDNA flanked by 400 bp chicken insulators ${ }^{25,26}$. The same vector will be applied to infants with XSCID in the future as well. The older patients treated so far received a mild conditioning regime. These patients had all previously failed haploidentical HSCT attempts. After treatment with autologous corrected CD34 cells, patients had gene marking in all lineages, functional T cell, NK and humoral reconstitution. Interestingly they were able to clear persistent norovirus (whereas prior IgG replacement failed), warts and molloscum (associated with NK cell reconstitution). Unfortunately one patient, with prior severely compromised pulmonary function and irreversible airway damage, died due to fatal pulmonary haemorrhage 27 months after gene therapy. Vector integration site analysis showed dynamic fluctuation in clonal integration sites near known oncogenes, but without any enrichment. Though follow-up in these patients is still too short to rule out any possible genotoxic adverse effects, both studies applying a SIN concept show promising results.

\section{Chronic Granulomatous Disease (CGD)}

CGD is caused by mutations in one of the subunits of the NADPH oxidase complex leading to disturbance in the phagocytic activity of neutrophils. The fully assembled complex consists of cytosolic phox proteins ( $\mathrm{p} 47^{\text {phox }}, \mathrm{p} 67^{\text {phox }}$ and $\left.\mathrm{p} 40^{\text {phox }}\right)$ translocated to the membranebound flavocytochrome (gp91 ${ }^{\text {phox }}$ and $\mathrm{p} 22^{\text {phox }}$ ) and upon assembly, reactive oxygen species (ROS) are produced to kill invading microbes. Mutations in the CYBB gene (encoding gp91phox) account for the majority of CGD patients, and is inherited in an X-linked manner and has been the target for gene therapy trials. Patients are susceptible to recurrent bacterial and fungal infections and furthermore sterile inflammation involves the respiratory, gastrointestinal and genitourinary tract. HSCT is successful in the early course, however the outcome declines with existing co-morbidities and lack of a suitable donor. ${ }^{27-29}$ Unlike in SCID, 
patients with defects in CGD have a fully replete marrow since the defect is due to a lack of peripheral neutrophil function and not of impaired development. For this reason, myeloablative conditioning is required to allow stem cell engraftment and achieve long-term correction as restoration of gp91 protein does not confer selective advantage over noncorrected cells. Furthermore CGD patients have an inflammatory bone marrow milieu which might influence HSC gene transfer and engraftment of gene modified cells negatively. ${ }^{30,31}$ The first trials in the late 90 s used a Mo-MLV based MFG gammaretrovirus on GCSF mobilized CD34+ HSCs. Five patients were treated without any preconditioning and as a result of this, only a transient production of neutrophils producing ROS could be detected and these studies failed to show any long-term clinical benefit. ${ }^{32,33}$ Other clinical trials around the world used LTR based gammaretroviral vectors and included the administration of a non-myeloablative conditioning regimen prior to gene transfer. A total of 13 patients were treated and ten patients experienced a transient clinical benefit with initial correction of NADPH activity and up to $50 \%$ of neutrophils showing gene marking, but over time, functional neutrophils did not persist. ${ }^{34-39}$ In two adults and one child the increase of gene marked neutrophils reflected clonal expansion and the viral SFFV LTR drove transactivation of the MDS/EVI1 and PRDM16 oncogenes leading to myelodysplasia (MDS) with monosomy 7. Both adult patients died due to complications in the context of MDS $34,37,40$. Another child treated at the same centre displayed clonal expansion without monosomy 7. Currently both younger patients are alive after HSCT ${ }^{35,38}$. Current clinical trials now employ SIN lentiviral vectors and include a fully myeloablative conditioning regime. Notably, one multicentre trial uses a lentiviral vector, in which gp91 ${ }^{\text {phox }}$ is driven by a synthetic chimeric promoter, created by the fusion of Cathepsin $\mathrm{G}$ and c-Fes minimal 5'-flanking regions. This vector allows preferential expression in myeloid 
cells and differentiated granulocytes and has a reduced potential regarding insertional mutagenesis. $^{41}$

\section{Wiskott-Aldrich-Syndrome}

WAS is an X-linked inherited disorder arising by mutations in the WAS gene, encoding WASp, a main actin cytoskeleton regulator protein. Patients usually manifest with microthrombocytopenia, eczema, infections and autoimmunity. ${ }^{42-44}$ HSCT in a matched-donor setting can cure the majority of patients, however as in other genetic disorders, a mismatched setting is associated with a higher rate of morbidity and mortality. Early murine studies have suggested a selective survival advantage of wild type over diseased cells. ${ }^{45}$ The first clinical gene therapy trial was conducted in Hannover in the 2000s and included ten patients lacking a matched family donor. An LTR intact gammaretroviral vector restored gene expression in the myeloid and lymphoid compartment in 9 of 10 patients with increased platelet numbers and normalized T, B and NK cell function and clear initial clinical benefit ${ }^{46}$; however 7 of 9 reconstituted patients developed acute leukaemia revealing dominant clones with integration in $L M O 2, M D S 1 / E V I 1$ and $M N 1$ oncogenes. ${ }^{47}$

Several SIN-LV vectors for the treatment of WAS have been developed by various groups ${ }^{48-51}$ to comply with safety requirements and have shown efficient transduction. A lentiviral vector consisting of the endogenous $1.6 \mathrm{~kb}$ human WAS promoter was chosen for clinical trials in Boston, London, Milan and Paris with preliminary results published recently ${ }^{52-55}$. All studies used a conditioning regime consisting of busulfan and fludarabine and a total of 21 patients have been treated so far. In most patients a stable engraftment of gene-marked cells could be seen associated with clear clinical benefits, in terms of bleeding episodes, infections autoimmunity and eczema. However, platelet recovery has been variable in all studies, 
indicating that WASp expression in this lineage might be suboptimal. There has been no evidence of any genotoxicity so far.

\section{Preclinical approaches in other primary immune disorders.}

In light of promising results in the four above mentioned disorders and other inherited diseases of the bone marrow, preclinical approaches to target other monogenic PIDs are currently being developed. V(D)J recombination defects account for one third of patients with SCID and lead to an inability to generate $T$ and B cell receptor. Patients suffering from recombinase activating gene (RAG1/2), Artemis (DCLRE1C) and Ligase IV (LIG4) deficiency usually present with a T- B- NK+ phenotype ${ }^{56,57}$. The latter, both being DNA repair disorders, are additionally associated with radiosensitivity, which is relevant for both HSCT and gene therapy. Several studies have highlighted lentivirus-mediated correction of murine and human HSCs in Artemis deficiency. Two early in-vivo studies showed sustained correction of $T$ and $B$ cell dysfunction in the mouse model. A lentiviral vector, in which Artemis expression was driven from an internal phosphoglycerate kinase (PGK) promoter, was used with Artemis knock-out HSCs, which were transplanted to either nonmyeolablative Busulfan conditioned or irradiated Artemis knock out mice. ${ }^{58,59}$ Furthermore bone marrow derived CD34+ cells from Artemis patients were successfully transduced, and repopulation studies in NSG mice showed the capability for further B and T cell differentiation of these cells. ${ }^{60}$ Two groups in the US have recently published their experience with a SIN lentiviral vector containing human Artemis cDNA under transcriptional regulation of the endogenous Artemis promoter. ${ }^{61,62}$ As the moderate-strength PGK gives insufficient immune reconstitution and human EF1 $\alpha$-drivenArtemis overexpression can be toxic, the use of the most "endogenous" promoter may have potential to be superior. Fibroblasts from patients transduced with that lentivirus showed correction of radiosensitivity. Furthermore the group demonstrated that transduced 
peripheral blood CD34+ cells from a patient as well as HSCs from Artemis-deficient mice are able to differentiate to $\mathrm{T}$ and $\mathrm{B}$ cells. Vector copy number and tight regulation of protein expression is also of major concern in preclinical models of both recombinase-activating genes. Early attempts corrected the murine model of RAG1 and 2 with MLV derived gammaretroviral vector allowing high vector copy numbers in all organs. ${ }^{63,64}$ However, to avoid risk of insertional mutagenesis new lentiviral vectors delivering a codon-optimized transgene have been developed. ${ }^{65,66}$ In RAG-1 reconstitution studies in the murine model, low VCN and low B cell reconstitution and RAG-1 expression lead to autoreactive T cells and an Omenn-like syndrome with a reduced thymic cellularity, emphasising the need for appropriate RAG-1 regulation to fully correct the disease phenotype. ${ }^{67}$ RAG-2 correction appears to be more readily achieved using an LV with a ubiquitous promoter and suggests that for RAG-2, there is a less stringent need for regulated gene expression. ${ }^{68}$

Inherited diseases associated with a reduced NK and CD8 cytotoxicity, such as Hemophagocytic Lymphohistiocytosis $(\mathrm{HLH})$, are also amenable to corrective strategies employing gene therapy. Proof-of-concept studies have been performed in murine models of perforin deficiency, Munc 13-4 deficiency and X-linked lymphoproliferative disease. ${ }^{69-71}$ Autologous T cell gene therapy is an equally attractive strategy in these disorders, as we know from early ADA trials (see above), that transplanted gene-transduced peripheral lymphocytes remain in the circulation for decades. ${ }^{72}$ The safety profile and long-term effects of these products have been investigated in numerous adoptive cell trials in cancer and infectious disease, so that we and other groups have performed murine T cell gene therapy studies in defects of the cytolytic pathway. Further genetic correction is currently investigated in preclinical models of IPEX syndrome, CD40L deficiency, p47 autosomal recessive CGD, 
Bruton's agammaglobulinemia and Leukocyte Adhesion Deficiency Type I. ${ }^{73-77}$

\section{Summary}

The new generation of gene therapy trials employs safer vectors and the use of myeloablative and non-myeloablative conditioning regimens. The occurrence of insertional mutagenesis and subsequent malignancies was strongly linked to the use of gammaretroviral vectors. A SIN configuration, lacking the enhancers of the LTR in U3 to avoid enhancer mediated activation, and using well-designed different internal promoters to drive transgene expression, and are the main changes in vector design. Short-term results are encouraging in terms of both safety and efficacy. Furthermore gene editing, especially for diseases where there is a need for more physiological gene regulation (which is discussed in Chapters 5 and 6 in this issue), will certainly lead to new opportunities in the treatment of these patients.

\section{Disclosure of conflicts of interest}

HBG is a founder and advisory board member of Orchard Therapeutics and has financial interests in the company. 


\begin{tabular}{|c|c|c|c|c|c|c|}
\hline $\begin{array}{l}\text { dise } \\
\text { ase }\end{array}$ & centre & status & $\begin{array}{l}\text { patien } \\
\text { ts }\end{array}$ & NCT & viral vector & conditioning \\
\hline \multirow[t]{5}{*}{ ADA } & $\begin{array}{l}\text { Los Angeles, } \\
\text { Bethesda, }\end{array}$ & $\mathrm{R}$ & 8 & $\begin{array}{l}\text { NCT01852071; } \\
\text { NCT02022696 }\end{array}$ & LV & $\begin{array}{l}\text { Busulfan / } \\
\text { ERT till } d+30\end{array}$ \\
\hline & London & $\mathrm{R}$ & 12 & NCT01380990 & LV & $\begin{array}{l}\text { Busulfan / } \\
\text { ERT till } d+30\end{array}$ \\
\hline & $\begin{array}{l}\text { Milan, } \\
\text { Jerusalem }\end{array}$ & $\mathrm{C}$ & 18 & $\begin{array}{l}\text { NCT00599781; } \\
\text { NCT00598481 }\end{array}$ & $y-R V$ & \\
\hline & Bethesda & C & 16 & NCT00018018 & $y-R V$ & $\begin{array}{l}\text { None / } \\
\text { Busulfan }\end{array}$ \\
\hline & London & $\mathrm{C}$ & 8 & NCT01279720 & $Y-R V$ & $\begin{array}{l}\text { Melphalan / } \\
\text { Busulfan }\end{array}$ \\
\hline \multirow[t]{6}{*}{$\begin{array}{l}\text { SCID } \\
-X 1\end{array}$} & $\begin{array}{l}\text { Boston, } \\
\text { Cincinatti } \\
\text { London, Los } \\
\text { Angeles, Paris }\end{array}$ & $\mathrm{R}$ & 11 & $\begin{array}{l}\text { NCT01410019; } \\
\text { NCT01175239; } \\
\text { NCT01129544 }\end{array}$ & SIN- $y-R V$ & None \\
\hline & $\begin{array}{l}\text { Memphis, } \\
\text { Seattle }\end{array}$ & $\mathrm{R}$ & 0 & NCT01512888 & LV & None \\
\hline & $\begin{array}{l}\text { Bethesda, } \\
\text { Memphis }\end{array}$ & $\mathrm{R}$ & 5 & NCT01306019 & LV & Busulfan \\
\hline & Bethesda & C & 3 & NCT00028236 & $\gamma-R V$ & None \\
\hline & London & C & 11 & & $Y-R V$ & None \\
\hline & Paris & C & 11 & & $\mathrm{Y}-\mathrm{RV}$ & None \\
\hline \multirow[t]{9}{*}{ CGD } & Frankfurt & $\mathrm{R}$ & 0 & NCT01906541 & SIN- $y-R V$ & Busulfan \\
\hline & $\begin{array}{l}\text { Frankfurt, } \\
\text { London, Paris, } \\
\text { Zürich }\end{array}$ & $\mathrm{R}$ & 1 & NCT01855685 & LV & Busulfan \\
\hline & $\begin{array}{l}\text { Bethesda, } \\
\text { Boston, Los } \\
\text { Angeles }\end{array}$ & $\mathrm{R}$ & 1 & NCT02234934 & LV & Busulfan \\
\hline & London & C & 4 & & $\gamma-R V$ & Melphalan \\
\hline & Frankfurt & C & 2 & NCT00564759 & $y-R V$ & Busulfan \\
\hline & Zürich & $\mathrm{C}$ & 2 & NCT00927134 & $y-R V$ & Busulfan \\
\hline & Seoul & C & 2 & NCT00778882 & $\gamma-R V$ & $\begin{array}{l}\text { Busulfan / } \\
\text { Fludarabine }\end{array}$ \\
\hline & Bethesda & $\mathrm{C}$ & 3 & NCT00394316 & $Y-R V$ & Busulfan \\
\hline & Bethesda & C & 10 & NCT00001476 & $y-R V$ & None \\
\hline \multirow[t]{3}{*}{ WAS } & $\begin{array}{l}\text { Boston, } \\
\text { London, Paris }\end{array}$ & $\mathrm{R}$ & 13 & $\begin{array}{l}\text { NCT01347242; } \\
\text { NCT01347346; } \\
\text { NCT01410825 }\end{array}$ & LV & $\begin{array}{l}\text { Busulfan / } \\
\text { Fludarabine }\end{array}$ \\
\hline & Milan & $\mathrm{R}$ & 10 & NCT01515462 & LV & \\
\hline & Hannover & C & 10 & & $y-R V$ & Busulfan \\
\hline
\end{tabular}

Table 1: Gene therapy clinical trials for primary immunodeficiencies. $\mathrm{R}=$ recruiting or not yet recruiting, $\mathrm{C}=$ completed / terminated / not recruiting any longer. 


\section{References}

1. Picard C, Al-Herz W, Bousfiha A, et al. Primary Immunodeficiency Diseases: an Update on the Classification from the International Union of Immunological Societies Expert Committee for Primary Immunodeficiency 2015. J Clin Immunol. 2015;35(8):696-726. doi: 10.1007/s10875-015-0201-1.

2. Booth C, Silva J, Veys P. Stem cell transplantation for the treatment of immunodeficiency in children: current status and hopes for the future. Expert Rev Clin Immunol. 2016;12(7):713-723. doi: 10.1586/1744666X.2016.1150177.

3. Whitmore KV, Gaspar HB. Adenosine Deaminase Deficiency - More Than Just an Immunodeficiency. Front Immunol. 2016;7:314. doi: 10.3389/fimmu.2016.00314.

4. Gaspar HB, Cooray S, Gilmour KC, et al. Hematopoietic stem cell gene therapy for adenosine deaminase-deficient severe combined immunodeficiency leads to longterm immunological recovery and metabolic correction. Sci Transl Med. 2011;3(97):97ra80. doi: 10.1126/scitransImed.3002716.

5. Blaese RM, Culver KW, Miller AD, et al. T lymphocyte-directed gene therapy for ADASCID: initial trial results after 4 years. Science. 1995;270(5235):475-480. http://www.ncbi.nlm.nih.gov/pubmed/7570001.

6. Bordignon C, Notarangelo LD, Nobili N, et al. Gene therapy in peripheral blood lymphocytes and bone marrow for ADA- immunodeficient patients. Science. 1995;270(5235):470-475. http://www.ncbi.nlm.nih.gov/pubmed/7570000.

7. Onodera M, Ariga T, Kawamura N, et al. Successful peripheral T-lymphocyte-directed gene transfer for a patient with severe combined immune deficiency caused by adenosine deaminase deficiency. Blood. 1998;91(1):30-36. http://www.ncbi.nlm.nih.gov/pubmed/9414266.

8. Aiuti A, Vai S, Mortellaro A, et al. Immune reconstitution in ADA-SCID after PBL gene therapy and discontinuation of enzyme replacement. Nat Med. 2002;8(5):423-425. doi: 10.1038/nm0502-423.

9. Aiuti A, Cattaneo F, Galimberti S, et al. Gene therapy for immunodeficiency due to adenosine deaminase deficiency. N Engl J Med. 2009;360(5):447-458. doi: 10.1056/NEJMoa0805817.

10. Candotti F, Shaw KL, Muul L, et al. Gene therapy for adenosine deaminase-deficient severe combined immune deficiency: clinical comparison of retroviral vectors and treatment plans. Blood. 2012;120(18):3635-3646. doi: 10.1182/blood-2012-02400937.

11. Carbonaro DA, Jin $X$, Wang $X$, et al. Gene therapy/bone marrow transplantation in ADA-deficient mice: roles of enzyme-replacement therapy and cytoreduction. Blood. 2012;120(18):3677-3687. doi: 10.1182/blood-2012-02-408591.

12. Schimmer J, Breazzano S. Investor Outlook: Rising from the Ashes; GSK's European Approval of Strimvelis for ADA-SCID. Hum Gene Ther Clin Dev. 2016;27(2):57-61. doi: 10.1089/humc.2016.29010.ind.

13. Carbonaro DA, Zhang $L$, Jin $X$, et al. Preclinical demonstration of lentiviral vectormediated correction of immunological and metabolic abnormalities in models of adenosine deaminase deficiency. Mol Ther. 2014;22(3):607-622. doi: 10.1038/mt.2013.265.

14. Gaspar HB, Buckland K, Carbonaro DA, et al. Immunological and Metabolic Correction After Lentiviral Vector Gene Therapy for ADA Deficiency. Paper presented at: 18th 
Annual Meeting of the American Society of Gene and Cell Therapy (ASGCT)2015; New Orleans, LA.

15. Fischer A, Notarangelo LD, Neven B, Cavazzana M, Puck JM. Severe combined immunodeficiencies and related disorders. Nat Rev Dis Primers. 2015;1:15061. doi: 10.1038/nrdp.2015.61.

16. Stephan V, Wahn V, Le Deist F, et al. Atypical X-linked severe combined immunodeficiency due to possible spontaneous reversion of the genetic defect in $T$ cells. N Engl J Med. 1996;335(21):1563-1567. doi: 10.1056/NEJM199611213352104.

17. Hacein-Bey-Abina S, Le Deist F, Carlier F, et al. Sustained correction of X-linked severe combined immunodeficiency by ex vivo gene therapy. $N$ Engl J Med. 2002;346(16):1185-1193. doi: 10.1056/NEJMoa012616.

18. Hacein-Bey-Abina S, Garrigue A, Wang GP, et al. Insertional oncogenesis in 4 patients after retrovirus-mediated gene therapy of SCID-X1. J Clin Invest. 2008;118(9):31323142. doi: 10.1172/JCI35700.

19. Gaspar HB, Cooray S, Gilmour KC, et al. Long-term persistence of a polyclonal T cell repertoire after gene therapy for X-linked severe combined immunodeficiency. Sci Transl Med. 2011;3(97):97ra79. doi: 10.1126/scitransImed.3002715.

20. Chinen J, Davis J, De Ravin SS, et al. Gene therapy improves immune function in preadolescents with X-linked severe combined immunodeficiency. Blood. 2007;110(1):67-73. doi: 10.1182/blood-2006-11-058933.

21. Deichmann A, Hacein-Bey-Abina $S$, Schmidt $M$, et al. Vector integration is nonrandom and clustered and influences the fate of lymphopoiesis in SCID-X1 gene therapy. J Clin Invest. 2007;117(8):2225-2232. doi: 10.1172/JCl31659.

22. Howe SJ, Mansour MR, Schwarzwaelder $\mathrm{K}$, et al. Insertional mutagenesis combined with acquired somatic mutations causes leukemogenesis following gene therapy of SCID-X1 patients. J Clin Invest. 2008;118(9):3143-3150. doi: 10.1172/JCI35798.

23. Thornhill SI, Schambach A, Howe SJ, et al. Self-inactivating gammaretroviral vectors for gene therapy of $\mathrm{X}$-linked severe combined immunodeficiency. Mol Ther. 2008;16(3):590-598. doi: 10.1038/sj.mt.6300393.

24. Hacein-Bey-Abina S, Pai SY, Gaspar HB, et al. A Modified gamma-Retrovirus Vector for X-Linked Severe Combined Immunodeficiency. N Engl J Med. 2014;371(15):1407-1417. doi: 10.1056/NEJMoa1404588.

25. Zhou S, Mody D, DeRavin SS, et al. A self-inactivating lentiviral vector for SCID-X1 gene therapy that does not activate $\mathrm{LMO} 2$ expression in human $\mathrm{T}$ cells. Blood. 2010;116(6):900-908. doi: 10.1182/blood-2009-10-250209.

26. De Ravin SS, Wu X, Moir S, et al. Lentiviral hematopoietic stem cell gene therapy for Xlinked severe combined immunodeficiency. Sci Transl Med. 2016;8(335):335ra357. doi: 10.1126/scitranslmed.aad8856.

27. Cole T, Pearce MS, Cant AJ, Cale CM, Goldblatt D, Gennery AR. Clinical outcome in children with chronic granulomatous disease managed conservatively or with hematopoietic stem cell transplantation. J Allergy Clin Immunol. 2013;132(5):11501155. doi: 10.1016/j.jaci.2013.05.031.

28. Holland SM. Chronic granulomatous disease. Hematol Oncol Clin North Am. 2013;27(1):89-99, viii. doi: 10.1016/j.hoc.2012.11.002.

29. Seger RA. Advances in the diagnosis and treatment of chronic granulomatous disease. Curr Opin Hematol. 2011;18(1):36-41. doi: 10.1097/MOH.0b013e32834115e7. 
30. Grez M, Reichenbach J, Schwable J, Seger R, Dinauer MC, Thrasher AJ. Gene therapy of chronic granulomatous disease: the engraftment dilemma. Mol Ther. 2011;19(1):2835. doi: 10.1038/mt.2010.232.

31. Weisser $M$, Demel UM, Stein $S$, et al. Hyperinflammation in patients with chronic granulomatous disease leads to impairment of hematopoietic stem cell functions. $J$ Allergy Clin Immunol. 2016;138(1):219-228 e219. doi: 10.1016/j.jaci.2015.11.028.

32. Malech HL, Maples PB, Whiting-Theobald N, et al. Prolonged production of NADPH oxidase-corrected granulocytes after gene therapy of chronic granulomatous disease. Proc Natl Acad Sci $U$ S A. 1997;94(22):12133-12138. http://www.ncbi.nlm.nih.gov/pubmed/9342375.

33. Goebel WS, Dinauer MC. Gene therapy for chronic granulomatous disease. Acta Haematol. 2003;110(2-3):86-92. doi: 72457.

34. Ott MG, Schmidt $M$, Schwarzwaelder $K$, et al. Correction of $X$-linked chronic granulomatous disease by gene therapy, augmented by insertional activation of MDS1-EVI1, PRDM16 or SETBP1. Nat Med. 2006;12(4):401-409. doi: 10.1038/nm1393.

35. Bianchi $M$, Hakkim $A$, Brinkmann $V$, et al. Restoration of NET formation by gene therapy in CGD controls aspergillosis. Blood. 2009;114(13):2619-2622. doi: 10.1182/blood2009-05-221606.

36. Kang EM, Choi U, Theobald N, et al. Retrovirus gene therapy for X-linked chronic granulomatous disease can achieve stable long-term correction of oxidase activity in peripheral blood neutrophils. Blood. 2010;115(4):783-791. doi: 10.1182/blood-200905-222760.

37. Stein S, Ott MG, Schultze-Strasser S, et al. Genomic instability and myelodysplasia with monosomy 7 consequent to EVI1 activation after gene therapy for chronic granulomatous disease. Nat Med. 2010;16(2):198-204. doi: 10.1038/nm.2088.

38. Bianchi M, Niemiec MJ, Siler U, Urban CF, Reichenbach J. Restoration of antiAspergillus defense by neutrophil extracellular traps in human chronic granulomatous disease after gene therapy is calprotectin-dependent. J Allergy Clin Immunol. 2011;127(5):1243-1252 e1247. doi: 10.1016/j.jaci.2011.01.021.

39. Kang HJ, Bartholomae CC, Paruzynski A, et al. Retroviral gene therapy for X-linked chronic granulomatous disease: results from phase $1 / 11$ trial. Mol Ther. 2011;19(11):2092-2101. doi: 10.1038/mt.2011.166.

40. Aiuti A, Bacchetta R, Seger R, Villa A, Cavazzana-Calvo M. Gene therapy for primary immunodeficiencies: Part 2. Curr Opin Immunol. 2012;24(5):585-591. doi: 10.1016/j.coi.2012.07.012.

41. Santilli G, Almarza E, Brendel C, et al. Biochemical correction of X-CGD by a novel chimeric promoter regulating high levels of transgene expression in myeloid cells. Mol Ther. 2011;19(1):122-132. doi: 10.1038/mt.2010.226.

42. Thrasher AJ. New insights into the biology of Wiskott-Aldrich syndrome (WAS). Hematology Am Soc Hematol Educ Program. 2009:132-138. doi: 10.1182/asheducation-2009.1.132.

43. Massaad MJ, Ramesh N, Geha RS. Wiskott-Aldrich syndrome: a comprehensive review. Ann N Y Acad Sci. 2013;1285:26-43. doi: 10.1111/nyas.12049.

44. Blundell MP, Worth A, Bouma G, Thrasher AJ. The Wiskott-Aldrich syndrome: The actin cytoskeleton and immune cell function. Dis Markers. 2010;29(3-4):157-175. doi: 10.3233/DMA-2010-0735.

45. Moratto D, Giliani S, Bonfim C, et al. Long-term outcome and lineage-specific chimerism in 194 patients with Wiskott-Aldrich syndrome treated by hematopoietic 
cell transplantation in the period 1980-2009: an international collaborative study. Blood. 2011;118(6):1675-1684. doi: 10.1182/blood-2010-11-319376.

46. Boztug $K$, Schmidt $M$, Schwarzer $A$, et al. Stem-cell gene therapy for the WiskottAldrich syndrome. N Engl J Med. 2010;363(20):1918-1927. doi: 10.1056/NEJMoa1003548.

47. Braun CJ, Boztug K, Paruzynski A, et al. Gene therapy for Wiskott-Aldrich syndrome-long-term efficacy and genotoxicity. Sci Transl Med. 2014;6(227):227ra233. doi: 10.1126/scitranslmed.3007280.

48. Avedillo Diez I, Zychlinski D, Coci EG, et al. Development of novel efficient SIN vectors with improved safety features for Wiskott-Aldrich syndrome stem cell based gene therapy. Mol Pharm. 2011;8(5):1525-1537. doi: 10.1021/mp200132u.

49. Dupre L, Marangoni F, Scaramuzza S, et al. Efficacy of gene therapy for Wiskott-Aldrich syndrome using a WAS promoter/CDNA-containing lentiviral vector and nonlethal irradiation. Hum Gene Ther. 2006;17(3):303-313. doi: 10.1089/hum.2006.17.303.

50. Marangoni F, Bosticardo M, Charrier S, et al. Evidence for long-term efficacy and safety of gene therapy for Wiskott-Aldrich syndrome in preclinical models. Mol Ther. 2009;17(6):1073-1082. doi: 10.1038/mt.2009.31.

51. Bosticardo $M$, Draghici $E$, Schena $F$, et al. Lentiviral-mediated gene therapy leads to improvement of B-cell functionality in a murine model of Wiskott-Aldrich syndrome. $J$ Allergy Clin Immunol. 2011;127(6):1376-1384 e1375. doi: 10.1016/j.jaci.2011.03.030.

52. Aiuti A, Biasco L, Scaramuzza S, et al. Lentiviral hematopoietic stem cell gene therapy in patients with Wiskott-Aldrich syndrome. Science. 2013;341(6148):1233151. doi: 10.1126/science.1233151.

53. Bosticardo M, Ferrua F, Cavazzana M, Aiuti A. Gene therapy for Wiskott-Aldrich Syndrome. Curr Gene Ther. 2014. http://www.ncbi.nlm.nih.gov/pubmed/25245089.

54. Castiello MC, Scaramuzza S, Pala F, et al. B-cell reconstitution after lentiviral vectormediated gene therapy in patients with Wiskott-Aldrich syndrome. J Allergy Clin Immunol. 2015. doi: 10.1016/j.jaci.2015.01.035.

55. Hacein-Bey Abina S, Gaspar HB, Blondeau J, et al. Outcomes following gene therapy in patients with severe Wiskott-Aldrich syndrome. JAMA. 2015;313(15):1550-1563. doi: 10.1001/jama.2015.3253.

56. Moshous D, Callebaut I, de Chasseval R, et al. Artemis, a novel DNA double-strand break repair/V(D)J recombination protein, is mutated in human severe combined immune deficiency. Cell. 2001;105(2):177-186. http://www.ncbi.nlm.nih.gov/pubmed/11336668.

57. Schwarz K, Gauss GH, Ludwig L, et al. RAG mutations in human B cell-negative SCID. Science. 1996;274(5284):97-99. http://www.ncbi.nlm.nih.gov/pubmed/8810255.

58. Benjelloun F, Garrigue A, Demerens-de Chappedelaine $C$, et al. Stable and functional lymphoid reconstitution in artemis-deficient mice following lentiviral artemis gene transfer into hematopoietic stem cells. Mol Ther. 2008;16(8):1490-1499. doi: 10.1038/mt.2008.118.

59. Mostoslavsky G, Fabian AJ, Rooney S, Alt FW, Mulligan RC. Complete correction of murine Artemis immunodeficiency by lentiviral vector-mediated gene transfer. Proc Natl Acad Sci U S A. 2006;103(44):16406-16411. doi: 10.1073/pnas.0608130103.

60. Lagresle-Peyrou C, Benjelloun F, Hue C, et al. Restoration of human B-cell differentiation into NOD-SCID mice engrafted with gene-corrected CD34+ cells isolated from Artemis or RAG1-deficient patients. Mol Ther. 2008;16(2):396-403. doi: 10.1038/sj.mt.6300353. 
61. Multhaup MM, Podetz-Pedersen $K M$, Karlen $A D$, et al. Role of transgene regulation in ex vivo lentiviral correction of artemis deficiency. Hum Gene Ther. 2015;26(4):232-243. doi: 10.1089/hum.2014.062.

62. Punwani D, Kawahara M, Yu J, et al. Lentivirus Mediated Correction of Artemisdeficient Severe Combined Immunodeficiency. Hum Gene Ther. 2016. doi: 10.1089/hum.2016.064.

63. Lagresle-Peyrou C, Yates F, Malassis-Seris M, et al. Long-term immune reconstitution in RAG-1-deficient mice treated by retroviral gene therapy: a balance between efficiency and toxicity. Blood. 2006;107(1):63-72. doi: 10.1182/blood-2005-05-2032.

64. Yates F, Malassis-Seris M, Stockholm D, et al. Gene therapy of RAG-2-/- mice: sustained correction of the immunodeficiency. Blood. 2002;100(12):3942-3949. doi: 10.1182/blood-2002-03-0782.

65. Pike-Overzet $\mathrm{K}$, Rodijk M, Ng YY, et al. Correction of murine Rag1 deficiency by selfinactivating lentiviral vector-mediated gene transfer. Leukemia. 2011;25(9):14711483. doi: 10.1038/leu.2011.106.

66. van Til NP, de Boer $\mathrm{H}$, Mashamba $\mathrm{N}$, et al. Correction of murine Rag2 severe combined immunodeficiency by lentiviral gene therapy using a codon-optimized RAG2 therapeutic transgene. Mol Ther. 2012;20(10):1968-1980. doi: 10.1038/mt.2012.110.

67. Pike-Overzet K, Baum C, Bredius RG, et al. Successful RAG1-SCID gene therapy depends on the level of RAG1 expression. J Allergy Clin Immunol. 2014;134(1):242-243. doi: 10.1016/j.jaci.2014.04.033.

68. van Til NP, Sarwari R, Visser TP, et al. Recombination-activating gene 1 (Rag1)-deficient mice with severe combined immunodeficiency treated with lentiviral gene therapy demonstrate autoimmune Omenn-like syndrome. J Allergy Clin Immunol. 2014;133(4):1116-1123. doi: 10.1016/j.jaci.2013.10.009.

69. Rivat $C$, Booth $C$, Alonso-Ferrero $M$, et al. SAP gene transfer restores cellular and humoral immune function in a murine model of $X$-linked lymphoproliferative disease. Blood. 2013;121(7):1073-1076. doi: 10.1182/blood-2012-07-445858.

70. Carmo M, Risma KA, Arumugam $\mathrm{P}$, et al. Perforin gene transfer into hematopoietic stem cells improves immune dysregulation in murine models of perforin deficiency. Mol Ther. 2015;23(4):737-745. doi: 10.1038/mt.2014.242.

71. Tiwari S, Hontz A, Terrell CE, et al. High Level of Perforin Expression Is Required for Effective Correction of Hemophagocytic Lymphohistiocytosis. Hum Gene Ther. 2016. doi: 10.1089/hum.2016.065.

72. Oliveira G, Ruggiero E, Stanghellini MT, et al. Tracking genetically engineered lymphocytes long-term reveals the dynamics of T cell immunological memory. Sci Trans/ Med. 2015;7(317):317ra198. doi: 10.1126/scitransImed.aac8265.

73. Leon-Rico D, Aldea $M$, Sanchez-Baltasar R, et al. Lentiviral Vector-Mediated Correction of a Mouse Model of Leukocyte Adhesion Deficiency Type I. Hum Gene Ther. 2016;27(9):668-678. doi: 10.1089/hum.2016.016.

74. Passerini L, Rossi Mel E, Sartirana C, et al. CD4(+) T cells from IPEX patients convert into functional and stable regulatory $\mathrm{T}$ cells by FOXP3 gene transfer. Sci Transl Med. 2013;5(215):215ra174. doi: 10.1126/scitrans/med.3007320.

75. Brown MP, Topham DJ, Sangster MY, et al. Thymic lymphoproliferative disease after successful correction of CD40 ligand deficiency by gene transfer in mice. Nat Med. 1998;4(11):1253-1260. doi: 10.1038/3233. 
76. Schejtman A, Cutrim Arago Filho W, Zinicola M, et al. Establishing the platform for clinical gene therapy of p47phox chronic granulomatous disease (CGD). Paper presented at: Changing the Face of Modern Medicine: Stem Cells and Gene Therapy 24th Annual Congress of European Society of Gene \& Cell Therapy2016; Florence, Italy.

77. Zinicola M, Schejtman A, Calero-Garcia M, Mussolino C, Thrasher AJ, Santilli G. Targeted gene therapy for the treatment of $X$-linked

agammaglobulinemia (XLA). Paper presented at: Changing the Face of Modern Medicine: Stem Cells and Gene Therapy -

24th Annual Congress of European Society of Gene \& Cell Therapy2016; Florence, Italy. 